\title{
AFLP Analysis of Phytophthora cactorum Isolates from Strawberry and Other Hosts: Implications for Identifying the Primary Source of Inoculum
}

\author{
H. Huang, Department of Horticulture, S. N. Jeffers, Department of Plant Pathology and Physiology, D. R. Layne, \\ Department of Horticulture, and G. Schnabel, Department of Plant Pathology and Physiology, Clemson University, \\ Clemson, SC 29634
}

\begin{abstract}
Huang, H., Jeffers, S. N., Layne, D. R., and Schnabel, G. 2004. AFLP analysis of Phytophthora cactorum isolates from strawberry and other hosts: Implications for identifying the primary source of inoculum. Plant Dis. 88:714-720.

Forty-seven isolates of Phytophthora cactorum from North America and Germany were subjected to amplified fragment length polymorphism (AFLP) analysis to investigate genetic diversity among isolates and geographical populations; 42 isolates were recovered from cultivated strawberry plants (Fragaria $\times$ ananassa), and five isolates had been recovered from plants in four other genera (Syringa, Abies, Malus, and Panax). From all isolates evaluated, 226 out of 264 markers $(85.6 \%)$ were polymorphic and provided 42 unique AFLP profiles. The genetic diversity among isolates of $P$. cactorum from strawberry was greater than that among isolates from the other hosts. Isolates collected during recent crown rot epidemics in strawberry fields in South Carolina were genetically diverse and scattered among isolates from other geographical areas in an unweighted pair-group mean analysis (UPGMA) dendrogram. Isolates collected during recent crown rot epidemics in North Carolina also were genetically diverse, but most isolates clustered with isolates collected in 1997 from Florida strawberry fields. These data suggest that recent outbreaks of Phytophthora crown rot in the southeastern United States resulted from use of transplants already infected or infested with $P$. cactorum rather than from endemic populations of this pathogen, which would affect recommendations for disease management.
\end{abstract}

Additional keywords: bare-root plants, fingerprinting, population genetic structure, population genetics, strawberry plugs

Plastic-mulch, annual-hill strawberry culture, also called plasticulture, is an intensive form of growing strawberries (Fragaria $\times$ ananassa) that has replaced commercial matted-row production in much of the southeastern United States (19). In this system, young, immature strawberry transplants are planted in early fall on fumigated, raised beds that are covered with black plastic mulch (18). Transplants are grown primarily in Canada and the very northern areas of the United States, where cool summer temperatures keep anthracnose (caused by Colletotrichum spp.) pressure low. Transplants for the southeastern region of the United States are either fieldgrown, freshly dug, bare-root plants that

Corresponding author: G. Schnabel

E-mail: schnabe@clemson.edu

Current address of $\mathrm{H}$. Huang: Wuhan Botanical Garden/Wuhan Institute of Botany, Chinese Academy of Sciences, Moshan, Wuhan City, Hubei 430074, P. R. China.

Technical Contribution No. 4873 of the Clemson University Experiment Station.

Accepted for publication 3 March 2004.

Publication no. D-2004-0430-01R

(C) 2004 The American Phytopathological Society are delivered directly to strawberry growers or are rooted cuttings that must undergo 6 weeks of maturation at a plug production farm, typically located in North Carolina or South Carolina, before being delivered to strawberry growers. After harvesting fruit the following spring, plants are destroyed because most cultivars suitable for plasticulture are extremely susceptible to anthracnose, which is common and can be devastating during the warm, humid summer months in this region (18).

In recent years, outbreaks of Phytophthora crown rot, caused by Phytophthora cactorum (24), have occurred in plasticulture fields in North Carolina, South Carolina, and Georgia (22; G. Schnabel, personal observation). This pathogen has a wide host range and can attack approximately 200 species in 50 genera and 60 families of plants worldwide $(4,15)$. On strawberry, it commonly causes crown rot, which affects the entire plant, and leather rot, which affects both immature and mature berries $(17,24)$. Crown rot is known to occur in several countries in Europe and the United States (24) and recently was reported in Spain (3). In South Carolina, crown rot has occurred sporadically over the years. However, in 1998, this disease occurred for the first time as a widespread problem, affecting fields across the state; similar outbreaks occurred in 1999, 2000, and 2002 (22). To date, the primary source of inoculum for these crown rot outbreaks has not been identified.

Determining the primary source of inoculum is critical for developing an effective strategy for managing Phytophthora crown rot on strawberries. Two possible sources of inoculum could be responsible for the recent disease outbreaks. P. cactorum may be endemic to grower fields, and transplants become infected after planting by naturally occurring inoculum. Alternatively, transplants could be infected or infested before coming into South Carolina, which implies that primary inoculum was acquired sometime during transplant production. Several observations suggest that $P$. cactorum may not be endemic in South Carolina. When several strawberry cultivars were planted at the same location, the disease did not occur in random patches among all cultivars as would be expected if the pathogen already were present in the soil; most sites were fumigated with methyl bromide prior to planting, which should have eliminated or greatly reduced levels of inoculum. The disease primarily has occurred in fields planted with transplants from specific transplant producers, and plants became uniformly diseased early in the season before environmental conditions were conducive for widespread dissemination of inoculum and subsequent infection.

Genetic fingerprinting of $P$. cactorum isolates may help to elucidate the origin of the disease outbreaks. However, attempts to distinguish isolates of $P$. cactorum from strawberry with molecular tools has been unsuccessful in the past (6). Recently, a new type of molecular marker system, which is based on amplified fragment length polymorphism (AFLP) analysis, was developed and has proven to be a highly reliable and sensitive tool for detecting genetic variation in the DNA of plant pathogenic fungi $(8,20,29)$. This technique combines restriction fragment length polymorphism (RFLP) analysis and polymerase chain reaction (PCR) technology, resulting in highly informative fingerprints. Briefly, genomic DNA is digested with a restriction enzyme, and adaptors of a defined sequence are ligated to both ends of all restriction fragments. PCR then is performed using specifically designed 
primers that allow only a subset of the restriction fragments to be amplified. Amplification products are separated on highresolution sequencing gels and then analyzed (30).

The objective of this study was to determine if genetic fingerprints of isolates of $P$. cactorum from strawberries and several other hosts (used for comparison) could be obtained and differentiated using AFLP analysis. This information may prove useful in identifying the source of primary inoculum for recent outbreaks of Phytophthora crown rot in South Carolina strawberry fields and in establishing a DNA fingerprint database, which may be used to identify the source of future outbreaks.

\section{MATERIALS AND METHODS}

Fungus isolates. In all, 47 isolates of $P$. cactorum, collected over a 31-year period (1970 to 2001), were used in this study (Table 1). Of these, 42 isolates were recovered from cultivated strawberry plants grown in six states in the United States, Canada, and Germany; most of these isolates were collected in North Carolina (22 isolates), South Carolina (five isolates), and Florida (six isolates) between 1997 and 2001. Five isolates from other host genera were used for comparison: two isolates came from apple trees, one in New York and one in South Carolina, and one isolate each was recovered from a Fraser fir tree in Wisconsin, a lilac bush in Wisconsin, and a ginseng plant in North Caro- lina. Isolates either were collected during this study, were obtained from colleagues, or already were present in a permanent collection at Clemson University maintained by $\mathrm{S}$. N. Jeffers. Isolates were stored on Difco cornmeal agar (Becton, Dickinson, and Co., Franklin Lakes, NJ) in 8-ml glass vials at $15^{\circ} \mathrm{C}$ in the dark. All isolates were examined morphologically to confirm identification as P. cactorum (4), and DNA from isolates that appeared genetically diverse was sequenced to further verify accurate species identification (data not shown).

DNA extraction and AFLP analysis. Isolates were grown on $10 \%$ clarified V8 juice agar at $25^{\circ} \mathrm{C}$ in the dark for 2 weeks. Mycelium was scraped from the surface of

Table 1. Characteristics of 47 isolates of Phytophthora cactorum from strawberry and other hosts

\begin{tabular}{|c|c|c|c|c|c|c|}
\hline \multirow[b]{2}{*}{ Host plant } & \multirow[b]{2}{*}{ Isolate no. } & \multicolumn{3}{|c|}{ Geographic origin } & \multirow{2}{*}{$\begin{array}{c}\text { Year } \\
\text { isolated }\end{array}$} & \multirow[b]{2}{*}{ Source $^{x}$} \\
\hline & & County & State & Country & & \\
\hline \multirow[t]{42}{*}{ Fragaria $\times$ ananassa } & SC.99-0472 & Pickens & $\mathrm{SC}$ & USA & 1999 & Jeffers \\
\hline & SC.99-2554 & Laurens & $\mathrm{SC}$ & USA & 1999 & Jeffers \\
\hline & SC.99-2785 & Lexington & $\mathrm{SC}$ & USA & 1999 & Jeffers \\
\hline & SC.00-0417A & Colleton & $\mathrm{SC}$ & USA & 2000 & Jeffers \\
\hline & SC.00-Chan & Lexington & $\mathrm{SC}$ & USA & 1999 & Jeffers \\
\hline & FL.97-35 & Hillsborough & FL & USA & 1997 & Legard \\
\hline & FL.97-37 & Hillsborough & FL & USA & 1997 & Legard \\
\hline & FL.97-40 & $\ldots{ }^{y}$ & FL & USA & 1997 & Legard \\
\hline & FL.97-41 & Hillsborough & FL & USA & 1997 & Legard \\
\hline & FL.97-42A & Hillsborough & FL & USA & 1997 & Legard \\
\hline & FL.97-44 & & FL & USA & 1997 & Legard \\
\hline & NC.99-47-1 & Pender & $\mathrm{NC}$ & USA & 1999 & Louws \\
\hline & NC.99-47-2 & Pender & $\mathrm{NC}$ & USA & 1999 & Louws \\
\hline & NC.99-130-3A & Pender & $\mathrm{NC}$ & USA & 1999 & Louws \\
\hline & NC.99-130-3C & Pender & $\mathrm{NC}$ & USA & 1999 & Louws \\
\hline & NC.99-130-5A & Pender & $\mathrm{NC}$ & USA & 1999 & Louws \\
\hline & NC.99-130-7 & Pender & $\mathrm{NC}$ & USA & 1999 & Louws \\
\hline & NC.99-1277 & Guilford & $\mathrm{NC}$ & USA & 1999 & Louws \\
\hline & NC.99-1280 & Moore & $\mathrm{NC}$ & USA & 1999 & Louws \\
\hline & NC.00-5901 & Moore & $\mathrm{NC}$ & USA & 2000 & Louws \\
\hline & NC.00-5912 & Chowan & $\mathrm{NC}$ & USA & 2000 & Louws \\
\hline & NC.01-440-1 & & $\mathrm{TN}$ & USA & 2001 & Louws \\
\hline & NC.01-519 & Wake & $\mathrm{NC}$ & USA & 2001 & Louws \\
\hline & NC.01-765 & Brunswick & $\mathrm{NC}$ & USA & 2001 & Louws \\
\hline & NC.01-917 & Moore & $\mathrm{NC}$ & USA & 2001 & Louws \\
\hline & NC.01-1341 & Martin & $\mathrm{NC}$ & USA & 2001 & Louws \\
\hline & NC.01-1342-1 & Duplin & $\mathrm{NC}$ & USA & 2001 & Louws \\
\hline & NC.01-1342-2 & Duplin & $\mathrm{NC}$ & USA & 2001 & Louws \\
\hline & NC.01-1490-1 & Wake & $\mathrm{NC}$ & USA & 2001 & Louws \\
\hline & NC.01-1490-2 & Wake & $\mathrm{NC}$ & USA & 2001 & Louws \\
\hline & NC.01-1490-3 & Wake & $\mathrm{NC}$ & USA & 2001 & Louws \\
\hline & NC.PL3-12-4C & Washington & $\mathrm{NC}$ & USA & $\ldots$ & Louws \\
\hline & NC.PL3-13-4P & Washington & $\mathrm{NC}$ & USA & $\ldots$ & Louws \\
\hline & NC.PL3-27-4P & Washington & $\mathrm{NC}$ & USA & $\ldots$ & Louws \\
\hline & OSU.190 & Suffolk & NY & USA & 1987 & Hansen \\
\hline & OSU.194 & Suffolk & NY & USA & 1985 & Hansen \\
\hline & OSU. $221 \mathrm{~A}^{\mathrm{z}}$ & $\ldots$ & $\ldots$ & Germany & $\ldots$ & Hansen \\
\hline & OSU.221B ${ }^{\mathrm{z}}$ & $\ldots$ & $\ldots$ & Germany & $\ldots$ & Hansen \\
\hline & OSU.227 & $\ldots$ & $\ldots$ & Germany & & Hansen \\
\hline & W.097 & Winnebago & WI & USA & 1989 & Jeffers \\
\hline & BR-153A ${ }^{z}$ & Cumberland & Nova Scotia & Canada & 1970 & Lévesque \\
\hline & $\mathrm{BR}-153 \mathrm{~B}^{\mathrm{z}}$ & Cumberland & Nova Scotia & Canada & 1970 & Lévesque \\
\hline Abies fraseri & W.177 & Waushara & WI & USA & 1990 & Jeffers \\
\hline Syringa meyeri & W.020 & Jefferson & WI & USA & 1986 & Jeffers \\
\hline \multirow{2}{*}{ Malus domestica } & SC.HH-Apple & Richland & $\mathrm{SC}$ & USA & 1996 & Jeffers \\
\hline & NY.188 & Ulster & NY & USA & 1982 & Jeffers \\
\hline Panax quinquefolia & SC.99-2225 & Transylvania & $\mathrm{NC}$ & USA & 1999 & Jeffers \\
\hline
\end{tabular}

${ }^{\mathrm{x}}$ Individuals that provided isolates: S. N. Jeffers, Clemson University, Clemson, SC; D. E. Legard, University of Florida, Gulf Coast Research and Education Center, Dover; F. J. Louws, North Carolina State University, Raleigh; E. M. Hansen, Oregon State University, Corvallis; A. Lévesque, Agriculture and Agri-Food Canada, Ottawa, Ontario.

y Information not available.

${ }^{\mathrm{z}}$ Similar isolate numbers ending with $\mathrm{A}$ and $\mathrm{B}$ are subcultures of the same isolate. 
the agar, washed with double deionized water, frozen in liquid nitrogen, and then ground into a fine powder with a mortar and pestle. Total genomic DNA was recovered from approximately $50 \mathrm{mg}$ of mycelium (21), and extracted DNA was treated with RNase A (1). DNA was quantified in a GeneQuant Pro spectrophotometer (Biochrom, Cambridge, England) and electrophoresed on $1 \%$ agarose gels together with $\lambda /$ HindIII size markers.

AFLP analysis was performed essentially as described previously (29) using the AFLP Analysis System for Microorganisms (Gibco BRL, Grand Island, NY), except that twice as much (i.e., $250 \mathrm{ng}$ ) genomic DNA (gDNA) was digested in a total volume of $16.5 \mu \mathrm{l}$. Genomic DNA was digested using $1 \mu \mathrm{l}$ of an EcoRI/MseI endonuclease mixture and $2.5 \mu \mathrm{l}$ of $5 \times$ reaction buffer for $2.5 \mathrm{~h}$ at $37^{\circ} \mathrm{C}$, and digests were confirmed by electrophoresis on $1 \%$ agarose gels. Then $12 \mu \mathrm{l}$ of adaptor ligation solution and $0.5 \mu \mathrm{l}$ of T4 DNA ligase were added to the digests in a total volume of $25 \mu \mathrm{l}$, and the solution was incubated at $20^{\circ} \mathrm{C}$ for at least $2 \mathrm{~h}$. The resulting DNA (template DNA) was diluted $5 x$ in TE buffer. PCR pre-amplification was performed in a $25.5-\mu$ l volume containing $2.5 \mu \mathrm{l}$ of template DNA, $40 \mathrm{ng}$ of primer EcoRI-0, $40 \mathrm{ng}$ of primer MseI-0, $2.5 \mu \mathrm{l}$ of 10× PCR buffer, and $0.1 \mu \mathrm{l}$ of Taq DNA polymerase ( 5 units $/ \mu \mathrm{l}$ ) for 20 cycles of the thermal profile: $94^{\circ} \mathrm{C}$ for $30 \mathrm{~s}, 56^{\circ} \mathrm{C}$ for 60 $\mathrm{s}$, and $72^{\circ} \mathrm{C}$ for $60 \mathrm{~s}$. The pre-amplified DNA was diluted 1:25 in TE buffer and used as template DNA for selective amplification. Primer pairs for the selective amplification were EcoRI plus two selective nucleotides (+2) and MseI plus one selective nucleotide (+1). Eight EcoRI+2/MseI+1 primer combinations were used for fingerprinting isolates of $P$. cactorum: $E$-AA $/ M$ A, $E$-AA $/ M$-T, $E$-AA $/ M$-G, $E$-AA $/ M$-C, $E$ $\mathrm{AC} / M-\mathrm{A}, E-\mathrm{AC} / M-\mathrm{T}, E-\mathrm{AC} / M-\mathrm{G}$, and $E-$ $\mathrm{AC} / M$-C. The $E c o$ RI primers were labeled by phosphorylating the $5^{\prime}$ end with $\left(\gamma_{-}{ }^{33} \mathrm{P}\right)$ ATP. An aliquot of 30 to $300 \mathrm{bp}$ of AFLP DNA ladder (Invitrogen, Carlsbad, CA) was used to determine the size of amplified DNA fragments. The selectively amplified products were denatured at $94^{\circ} \mathrm{C}$ for $3 \mathrm{~min}$ with an equal volume of denaturing solution (98\% formamide) and were electrophoresed on $6 \%$ polyacrylamide sequencing gels containing $1 \times$ TBE running buffer at $70 \mathrm{~W}$ of constant power for approximately $3 \mathrm{~h}$. The gel was transferred onto 3 MM chromatography paper (Whatman, Kent, UK), dried in a vacuum gel dryer, and exposed to X-ray film (Kodak BioMax MR, Rochester, NY) for 1 to 2 days. Each DNA sample was amplified at least two times to verify the reproducibility of the AFLP technique.

Marker scoring and data analysis. Only intense and unambiguous bands were scored as present (1) or absent (0); all AFLP fingerprint patterns were evaluated and scored manually. The AFLP markers were designated according to the EcoRI/MseI primer combination used for amplification, followed by a three-digit number indicating the product size in base pairs. Using all 47 isolates, 264 bands were scored, which resulted in a $47 \times 264$ binary matrix. This data set was analyzed using POPGENE ver. 1.32 (31) and NTSYS-pc ver. 1.8 (Exeter Software, Setauket, NY) software programs. A set of intra- and inter-population genetic statistics was estimated and corrected for both small sample size (14) and the small number of populations studied (12). The genetic statistics in this set were: the percentage of polymorphic loci $(P, 99 \%$ criterion) (11), gene diversity $(h)$, Shannon and Weaver's index (I) (25), total genetic diversity $\left(H_{T}\right)$, genetic diversity within populations $\left(H_{S}\right)$, genetic diversity among populations $\left(D_{S T}\right)$, the relative magnitude of genetic differentiation among populations $\left(G_{S T}=D_{S T} / H_{T}\right)(13)$, and the $\mathrm{G}^{2}$ test for heterogeneity of allele frequencies among populations, which was used to test for significant heterogeneity of allele frequencies. Gene flow $\left(N_{m}\right)$ was estimated from $G_{S T}$ (26). Nei and Li's genetic distances and identities (14) were calculated for all pairwise combinations of populations. Dendrograms for both isolates and geographical populations were constructed based on a matrix of genetic distances (14) using unweighted pair-group mean analysis (UPGMA).

\section{RESULTS}

Genetic diversity. AFLP analysis produced a large number of reproducible and unambiguous markers for fingerprinting the isolates of $P$. cactorum used in this study. Eight EcoRI+2/Mse I+1 primer pair combinations resolved 264 markers that could be scored reliably. Across all 47 isolates evaluated, 226 markers (85.6\%) were polymorphic and produced 42 unique AFLP profiles. Most isolates were uniquely identified by the AFLP profiles; however, no genetic differences were detected between three pairs and one trio of isolates: FL.97-41 and NC.99-130-7, NC.00-5912 and NC.01-917, OSU.221A and OSU.221B; and FL.97-37, NC.99130-3C, and NC.01-1342-1 (Fig. 1). The greatest genetic distance within a geographical population occurred between isolate NC.01-765 and the other isolates from North Carolina (Fig. 1). For populations of $P$. cactorum from North America, genetic diversity was greatest in populations from North Carolina and South Carolina and was lower in populations from Florida, New York, and Canada; polymorphic loci $(P)$ ranged from 1.5 to $69.7 \%$, gene diversity $(h)$ ranged from 0.0063 to 0.2042 , and the Shannon index $(I)$ ranged from 0.0092 to 0.3157 in populations from New York and North Carolina, respectively (Table 2). The average polymorphic loci, gene diversity, and Shannon index from North American populations were $20.6 \%$, 0.066 , and 0.1003 , respectively (Table 2 ).

Genetic structure. Partitioning of population genetic diversity based on the 264 AFLP markers showed that $43 \%$ of the genetic diversity occurred within populations based on mean $H_{S}$ and $H_{T}$ values of 0.0378 and 0.1036 , respectively (Table 3). This result also was reflected by Nei's $G_{S T}$ value (mean $\left.=0.635\right)$, which measured the proportion of total genetic diversity occurring among populations (Table 3). A contingency $\mathrm{G}^{2}$ analysis for heterogeneity of allele frequencies across the populations showed significance in 22 of the 226 polymorphic markers, suggesting divergence was significant among the populations of $P$. cactorum examined in this study (Table 3). Gene flow among the populations was extremely low, with $\mathrm{Nm}$ $=0.2875$ (Table 3$)$.

Genetic identity and distance were estimated based on AFLP allele frequencies using pairwise comparisons of populations (Table 4). Pairwise comparisons of six populations (unbiased estimates) revealed a mean genetic identity of 0.9346 , ranging from 0.9018 (between Germany and Canada) to 0.9671 (between North Carolina and Florida). The Germany population, although only consisting of three isolates, revealed high genetic identity to two populations in the United States-North Carolina and Florida-with a mean genetic identity of 0.9532 , but it appeared to be more distant from the South Carolina, New York, and Canada populations with a mean genetic identity of 0.9132 . Of the six geographical populations, North Carolina and Florida had the highest (0.9467 and 0.9441 , respectively) and Canada had the lowest (0.9223) average genetic identity.

Results for genetic distance estimates were very similar to those for genetic identity estimates (Table 4). In pairwise comparisons of the six populations, the overall average genetic distance was 0.0678 ; average genetic distances between populations ranged from 0.0335 (between North Carolina and Florida) to 0.1033 (between Canada and Germany). The North Carolina population had the lowest (0.0549) and the Canada population had the highest (0.0809) average genetic distance. Average genetic distances were relatively low for Florida (0.0577) and New York (0.0661) and relatively high for Germany (0.0737) and South Carolina (0.0735).

Genetic relationships. Genetic relationships among isolates of $P$. cactorum from strawberry and other hosts were examined further by UPGMA cluster analysis (Figs. 1 and 2). Relationships among the 47 isolates resulted in three major clusters (accounting for 41 isolates) and six genetically diverse isolates (five from strawberry: SC.00-0417A, NC.99-1277, SC.99-2785, NC.01-1490-1, and NC.01-765; and one from apple: NY.188) (Fig. 1). In one clus- 
ter of eight isolates from strawberry, three isolates came from North Carolina, two from South Carolina, two from New York, and one from Wisconsin. A cluster of seven isolates contained four of the isolates from hosts other than strawberry, two subcultures of BR-153 from strawberry in Canada, and one strawberry isolate from North Carolina. The main cluster contained 26 isolates from strawberry: most of the iso- lates from North Carolina (15/22), all of the isolates from Florida (six) and Germany (three), the one isolate from Tennessee, and one isolate from South Carolina. Strawberry isolates from South Carolina showed much genetic diversity; they were scattered throughout the dendrogram and often did not cluster with other isolates.

Relationships among geographical populations of isolates are displayed in another dendrogram (Fig. 2). This unrooted dendrogram revealed three distinct clusters, with most isolates in two clusters. Strawberry isolates from South Carolina, Germany, Florida, Tennessee, North Carolina, and Wisconsin were clustered, and isolates from hosts other than strawberry clustered. Interestingly, strawberry isolates from Canada clustered with isolates from different hosts, and the two isolates from

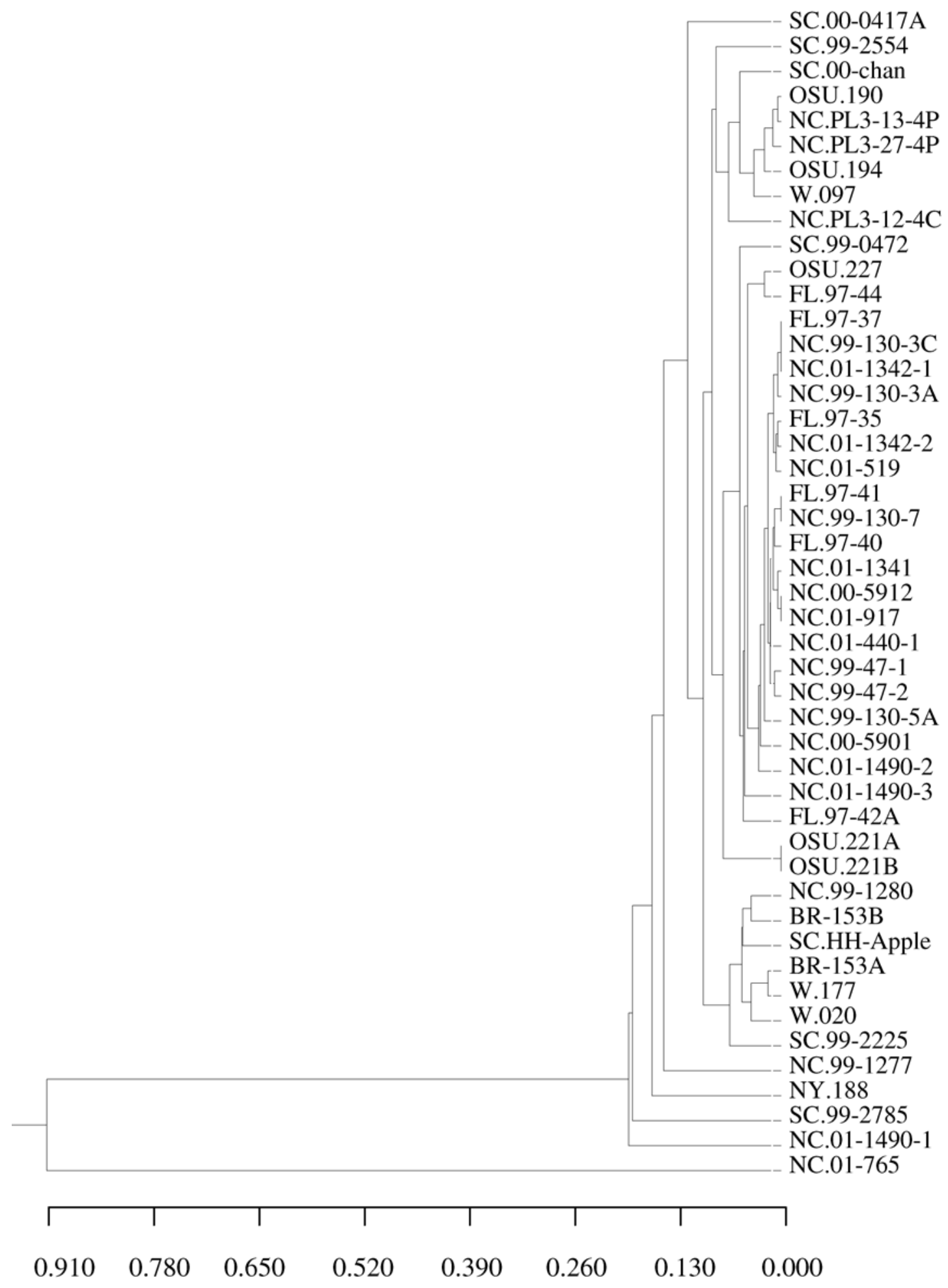

Fig. 1. Unweighted pair-group mean analysis dendrogram illustrating Nei's genetic distance (11) based on amplified fragment length polymorphisms from 47 isolates of Phytophthora cactorum recovered from cultivated strawberries and other hosts in South Carolina, North Carolina, Tennessee, Florida, New York, Wisconsin, Canada, and Germany. 
New York formed a separate cluster that was genetically distinct.

\section{DISCUSSION}

The genetic diversity among isolates of $P$. cactorum from $F$. $\times$ ananassa was greater than the genetic diversity among isolates from Syringa, Abies, Malus, and Panax. This result is in contrast to previous studies, in which genetic variation was considerable among isolates of $P$. cacto- rum from different hosts but was relatively low among isolates from the same host. Random amplified microsatellite (RAMS) markers used on $P$. cactorum isolates from different hosts produced patterns that reflected plant origin (6). Similar observations of coevolution between pathogens and hosts were demonstrated for isolates in the species of the genus Venturia (23). RAMS analysis indicated no genetic variation among strawberry isolates of $P$. cacto-

Table 2. Polymorphic loci $(P)$, gene diversity $(h)$, and Shannon index $(I)$ for populations of Phytophthora cactorum isolated from strawberry plants in four states in the eastern United States, Canada, and Germany

\begin{tabular}{lcccc}
\hline Population & Isolates (no.) & $\boldsymbol{P}(\boldsymbol{\%})$ & $\boldsymbol{h}^{\mathbf{y}}$ & $\boldsymbol{I}$ \\
\hline South Carolina & 5 & 24.24 & 0.0871 & 0.1301 \\
North Carolina & 22 & 69.70 & 0.2042 & 0.3157 \\
New York & 2 & 1.52 & 0.0063 & 0.0092 \\
Florida & 6 & 4.92 & 0.0214 & 0.0307 \\
Canada & 2 & 2.65 & 0.0110 & 0.0160 \\
North America mean & $\mathrm{z}$ & 20.61 & 0.0660 & 0.1003 \\
Germany & 3 & 4.92 & 0.0204 & 0.0298 \\
\hline
\end{tabular}

y Gene diversity ( $h$ ) was determined according to Nei (11).

${ }^{\mathrm{z}}$ Mean values for the five North American populations.

Table 3. Main loci, total genetic diversity $\left(H_{T}\right)$, genetic diversity within populations $\left(H_{S}\right)$, relative magnitude of genetic differentiation among populations $\left(G_{S T}\right)$, gene flow $\left(N_{m}\right)$, and heterogeneity of allele frequencies $\left(\mathrm{G}^{2}\right)$ of populations based on the 47 isolates of Phytophthora cactorum used in this study

\begin{tabular}{|c|c|c|c|c|c|}
\hline Main locus ${ }^{y}$ & $\boldsymbol{H}_{T}$ & $\boldsymbol{H}_{S}$ & $G_{S T}$ & $N_{m}$ & $\mathbf{G}^{2 \mathrm{z}}$ \\
\hline$E \mathrm{AA} / M \mathrm{G}-140$ & 0.4905 & 0.0804 & 0.8361 & 0.0980 & $22.10 *$ \\
\hline$E \mathrm{AA} / M \mathrm{G}-134$ & 0.4489 & 0.1046 & 0.7670 & 0.1519 & $21.68^{*}$ \\
\hline$E \mathrm{AC} / M \mathrm{~A}-300$ & 0.1208 & 0.0291 & 0.7590 & 0.1587 & $21.24 *$ \\
\hline$E$ AC/MA-290 & 0.2567 & 0.0782 & 0.6953 & 0.2191 & $21.15^{*}$ \\
\hline$E A C / M A-204$ & 0.2778 & 0.0000 & 1.0000 & 0.0000 & $22.18 *$ \\
\hline$E \mathrm{AC} / M \mathrm{~A}-124$ & 0.4467 & 0.1052 & 0.7645 & 0.1540 & $25.51 * *$ \\
\hline$E \mathrm{AC} / M \mathrm{~A}-121$ & 0.4965 & 0.1840 & 0.6295 & 0.2943 & $25.25^{* *}$ \\
\hline$E \mathrm{AC} / M \mathrm{~A}-108$ & 0.4467 & 0.1052 & 0.7645 & 0.1540 & $25.51 * *$ \\
\hline$E \mathrm{AC} / M \mathrm{~T}-285$ & 0.1208 & 0.0291 & 0.7590 & 0.1587 & $21.24 *$ \\
\hline$E \mathrm{AC} / M \mathrm{~T}-270$ & 0.1676 & 0.0437 & 0.7392 & 0.1764 & $19.76 *$ \\
\hline$E \mathrm{AC} / M \mathrm{~T}-200$ & 0.4991 & 0.0763 & 0.8471 & 0.0902 & $25.46^{* *}$ \\
\hline$E A C / M T-174$ & 0.4219 & 0.0573 & 0.8642 & 0.0786 & $29.61 * *$ \\
\hline$E \mathrm{AC} / M \mathrm{~T}-172$ & 0.4444 & 0.0000 & 1.0000 & 0.0000 & $31.63 * *$ \\
\hline$E A C / M T-159$ & 0.4461 & 0.0828 & 0.8144 & 0.1139 & $26.39 * *$ \\
\hline$E \mathrm{AC} / M \mathrm{~T}-111$ & 0.4994 & 0.0301 & 0.9397 & 0.0321 & $34.78 * *$ \\
\hline$E \mathrm{AC} / M \mathrm{G}-117$ & 0.1778 & 0.0761 & 0.5721 & 0.3739 & $19.73^{*}$ \\
\hline$E \mathrm{AC} / M \mathrm{C}-122$ & 0.3867 & 0.0679 & 0.8244 & 0.1065 & $23.77 *$ \\
\hline$E \mathrm{AC} / M \mathrm{C}-120$ & 0.4595 & 0.0345 & 0.9249 & 0.0406 & $35.36^{* *}$ \\
\hline$E A C / M C-118$ & 0.4630 & 0.1037 & 0.7761 & 0.1443 & $21.41 *$ \\
\hline$E \mathrm{AC} / M \mathrm{C}-116$ & 0.4399 & 0.0625 & 0.8580 & 0.0828 & $23.22 *$ \\
\hline$E \mathrm{AA} / M \mathrm{~T}-133$ & 0.2760 & 0.1051 & 0.6192 & 0.3075 & $22.36^{*}$ \\
\hline$E \mathrm{AA} / M \mathrm{~T}-107$ & 0.4243 & 0.0696 & 0.8359 & 0.0982 & $20.17 *$ \\
\hline \multicolumn{6}{|l|}{ Mean of all } \\
\hline 264 markers: & 0.1036 & 0.0378 & 0.6350 & 0.2875 & \\
\hline
\end{tabular}

rum from Finland, Estonia, Sweden, Germany, England, and Scotland. Therefore, it was suggested that a single clone may have caused crown rot of strawberry within the geographical region studied (6). Similarly, no genetic variation was found among isolates of $P$. cactorum from strawberry using RAPD markers (2).

The genetic variability among isolates of $P$. cactorum from strawberry in this study was significantly greater than the genetic variability among European isolates that was determined with isozymes (16), RAPDs (9), and RAMS analyses $(5,6)$. This observation may be explained by the resolving power of the AFLP analysis method used in this study, which appears to be a better tool for discriminating isolates of $P$. cactorum from a single host. The high sensitivity of the AFLP technique has proven valuable in various studies on genetic variation in fungi, including other species of Phytophthora $(10,27,28)$.

The 34 isolates of $P$. cactorum from strawberry plants in South Carolina, North Carolina, Tennessee, and Florida were obtained primarily from transplants grown under the plasticulture production system between 1997 and 2001. The scattered distribution of genetic fingerprints and overall genetic diversity of isolates from South Carolina and North Carolina suggest that these isolates are not endemic to strawberry fields in these states. The six isolates from Florida were genetically close and had little gene diversity. However, this is not unexpected because these isolates were obtained in 1997 from six different growers that had purchased transplants from the same supplier, which suggests that all six isolates originated from a common parent. Therefore, it is likely that the strawberry plants used in these states were infested or infected with $P$. cactorum prior to field planting. In addition, the relatively tight genetic clustering of isolates from North Carolina, Florida, and Tennessee suggests these isolates have a common ancestor and, therefore, were introduced.

Other evidence supports the hypothesis that $P$. cactorum on strawberries was introduced on transplants in the southeastern United States. First, the genetic diversity of isolates from an endemic population would have been expected to be low due to the homothallic nature of this pathogen. This was true for Florida isolates but not for

Table 4. Amplified fragment length polymorphism-based estimates of Nei's (11) unbiased genetic identity (above the diagonal) and unbiased genetic distance (below the diagonal) between populations of Phytophthora cactorum isolated from strawberry plants in four states in the eastern United States, Canada, and Germany

\begin{tabular}{|c|c|c|c|c|c|c|}
\hline Populations & South Carolina & New York & Germany & Florida & North Carolina & Canada \\
\hline South Carolina & & 0.9338 & 0.9195 & 0.9322 & 0.9442 & 0.9160 \\
\hline New York & 0.0685 & & 0.9184 & 0.9396 & 0.9462 & 0.9426 \\
\hline Germany & 0.0839 & 0.0851 & & 0.9588 & 0.9475 & 0.9018 \\
\hline Florida & 0.0702 & 0.0623 & 0.0421 & & 0.9671 & 0.9229 \\
\hline North Carolina & 0.0574 & 0.0553 & 0.0539 & 0.0335 & & 0.9283 \\
\hline Canada & 0.0877 & 0.0591 & 0.1033 & 0.0802 & 0.0744 & \\
\hline
\end{tabular}


isolates from North Carolina and South Carolina. The lack of genetic diversity among Florida isolates could be the result of isolates being introduced on transplants from a single source. If isolates came from endemic populations, it would be expected that isolates from the same geographic location would cluster. Instead, in this study, isolates from different locations were intermixed within dendrogram clusters. Second, P. cactorum was isolated from transplants received by South Carolina growers in both 2000 and 2001 (S. N. Jeffers, unpublished). Third, the standard procedure for soil preparation for plasticul- ture includes fumigation before planting (7), and the products typically used to fumigate strawberry fields eliminate or greatly reduce soilborne plant pathogens, including Phytophthora spp. Therefore, indigenous populations of $P$. cactorum would be greatly reduced prior to transplanting. In fall 2002 (before fumigating), $P$. cactorum was not detected in soil samples taken from several strawberry fields in South Carolina where crown rot had been a problem in the 2001-2002 growing season (S. N. Jeffers, unpublished). Lastly, South Carolina strawberry growers did not experience serious economic losses from

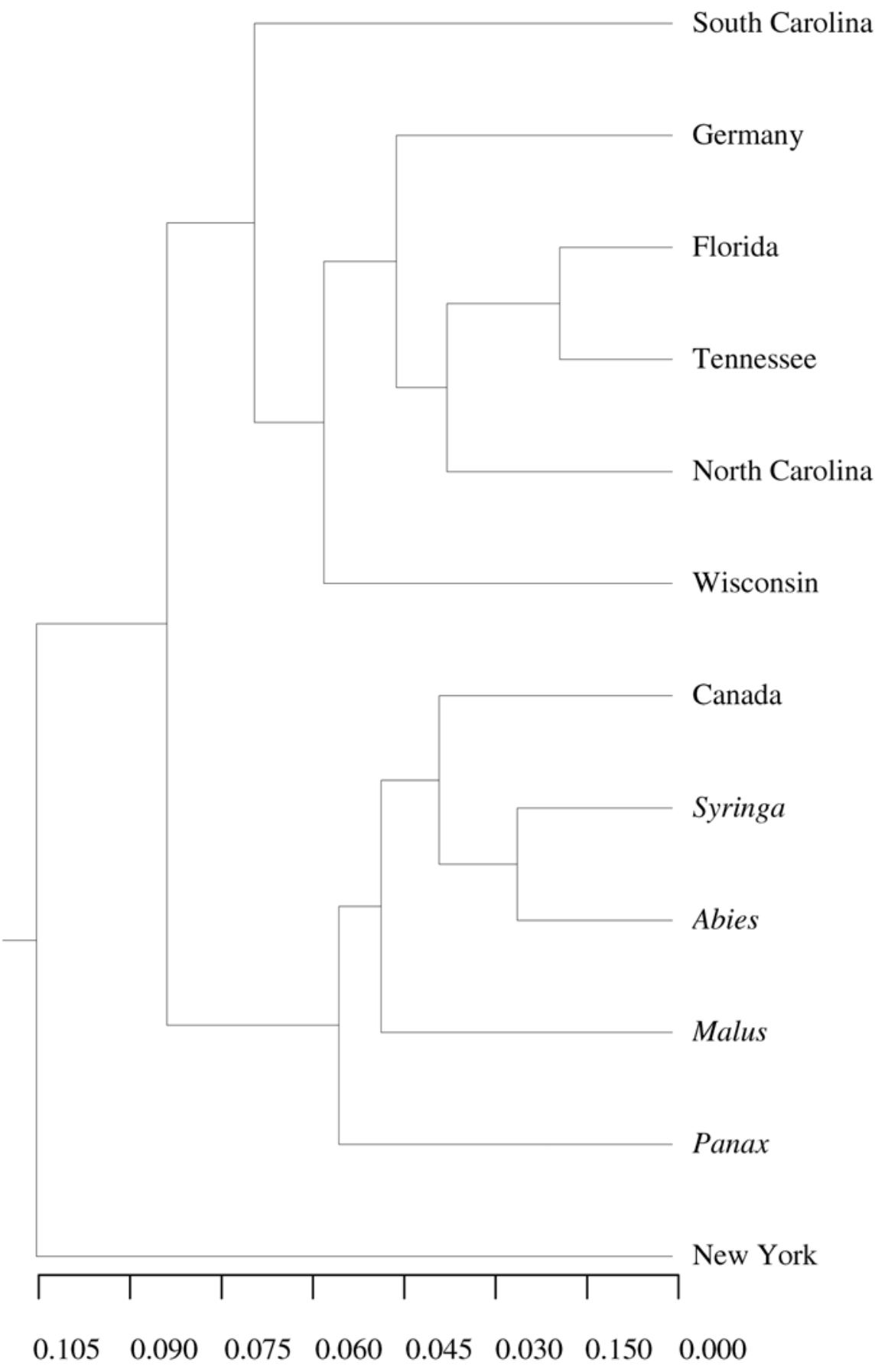

Fig. 2. Unweighted pair-group mean analysis dendrogram illustrating Nei's genetic distance (11) based on amplified fragment length polymorphisms from geographical populations of Phytophthora cactorum from cultivated strawberries and four other host genera: Abies, Malus, Panax, and Syringa.
Phytophthora crown rot prior to 1998, suggesting that endemic populations of $P$. cactorum, if present, typically exert only a low level of disease pressure.

Although the results of this study suggest that strawberry plants are the primary source of inoculum for Phytophthora crown rot in the southeastern United States, we were not able to accurately determine when or where in the production cycle plants became contaminated. The transplants could have been infected either at the initial sites of propagation (most of which are in Canada) or at plug production farms (several of which are in North Carolina and South Carolina). The two Canadian isolates included in this study were genetically distinct from all other isolates obtained from strawberry. However, these were subcultures from a common parent and, in contrast to most other isolates, were collected more than 30 years ago. Therefore, these two isolates probably are not representative of the current population of $P$. cactorum that occurs on strawberry in Canada.

The findings from this study have significant implications for crown rot management in the eastern United States. Historically, the disease has been controlled preventatively or curatively with fungicides. Protective fungicide application strategies are costly and may result in unnecessary use of chemicals when disease is absent. Alternatively, curative, postinfection fungicide application strategies may result in plant losses if products are not applied in a timely manner. This type of application strategy also promotes development of fungicide resistance in pathogen populations. Because P. cactorum may be introduced with transplants, strawberry growers could eliminate or reduce fungicide use in the field by: (i) purchasing disease-free transplants from a reliable supplier; (ii) encouraging tip or transplant producers to manage the disease problem before shipping transplants; and (iii) treating the plants with fungicides before transplanting if crown rot is diagnosed or suspected.

AFLP fingerprint analysis proved to be a powerful tool for characterizing individual isolates of $P$. cactorum. We created the first AFLP database for this pathogen, which may prove useful in the future for tracing the origin of new disease outbreaks in the eastern United States. AFLP fingerprints for isolates from new outbreaks could be analyzed and compared with those in the existing database. We also may be able to monitor existing isolates for movement due to natural dispersal or human activities.

\section{ACKNOWLEDGMENTS}

We thank the North American Strawberry Growers Association and the Southern Region Small Fruit Consortium for financial support, and L. A. Luszcz and C.-h. Duan for technical assistance. This project is based upon work supported 
by the CSREES/USDA, under project numbers SC1700159 and SC-1700177.

\section{LITERATURE CITED}

1. Ausubel, F. M., Brent, R., Kingston, P. E., Moore, D. D., Seidman, J. G., Smith, J. A., and Struhl, K. 2001. Current Protocols in Molecular Biology. John Wiley \& Sons, Indianapolis, IN.

2. Cooke, D. E. L., Kennedy, D. M., Guy, D. C., Russell, J., Unkles, S. E., and Duncan, J. M. 1996. Relatedness of group I species of $P h y$ tophthora as assessed by randomly amplified polymorphic DNA (RAPDs) and sequences of ribosomal DNA. Mycol. Res. 100:297-303.

3. de los Santos, B., Porras, M., Blanco, C., Barrau, C., and Romero, F. 2002. First report of Phytophthora cactorum on strawberry plants in Spain. Plant Dis. 86:1051.

4. Erwin, D. C., and Ribeiro, O. K. 1996. Phytophthora Diseases Worldwide. American Phytopathological Society, St. Paul, MN.

5. Hantula, J., Lilha, A., Nuoteva, H., Parikka, P., and Werres, S. 2000. Pathogenicity, morphology, and genetic variation of Phytophthora cactorum from strawberry, apple, rhododendron, and silver birch. Mycol. Res. 104:10621068.

6. Hantula, J., Lilha, A., and Parikka, P. 1997. Genetic variation and host specificity of Phytophthora cactorum isolated in Europe. Mycol. Res. 101:565-572.

7. Himelrick, D. G., Woods, F. M., Dozier, W. A., and Williams, J. D. 1995. Soil fumigation and soil solarization in the annual-hill strawberry plasticulture system. Adv. Strawberry Res. 14:69-72.

8. Lamour, K. H., and Hausbeck, M. K. 2001. The dynamics of mefenoxam insensitivity in a recombining population of Phytophthora capsici characterized with amplified fragment length polymorphism markers. Phytopathology 91:553-557.

9. Lilha, A., Karhalainen, R., Parikka, P., Kammiovirta, K., and Nuoteva, H. 1998. Patho- genicity and genetic variation of Phytophthora cactorum from silver birch and strawberry. Eur. J. Plant Pathol. 104:529-535.

10. Majer, D., Mithen, R., Lewis, B. G., Vos, P., and Oliver, R. P. 1996. The use of AFLP fingerprinting for the detection of genetic variation in fungi. Mycol. Res. 100:1107-1111.

11. Nei, M. 1973. Analysis of gene diversity in subdivided populations. Proc. Nat. Acad. Sci. 70:3321-3323

12. Nei, M. 1986. Definition and estimation of fixation indices. Evolution 40:643-645.

13. Nei, M. 1987. Molecular Evolution Genetics. Columbia University Press, New York.

14. Nei, M., and Li, W. H. 1979. Mathematical model for studying genetic variation in terms of restriction endonucleases. Proc. Nat. Acad. Sci. 76:5269-5273.

15. Nienhaus, F. 1960. Das Wirtsspektrum von Phytophthora cactorum (Leb. et Cohn) Schroet. Phytopathol. Z. 38:33-68.

16. Oudemans, P., and Coffey, M. D. 1991. Isozyme comparison within and among worldwide sources of three morphologically distinct species of Phytophthora. Mycol. Res. 95:19-30.

17. Parikka, P. 1991. Phytophthora cactorum on strawberry in Finland. Nord. Jordbrugsforsk. 73:121.

18. Poling, E. B. 1993. Strawberry plasticulture in North Carolina. II. Preplant, planting, and postplant considerations for growing 'Chandler' strawberry on black plastic mulch. HortTechnology 3:383-393.

19. Poling, E. B. 1993. Strawberry plasticulture in North Carolina. I. Developing a competitive horticultural industry requires "experts," not "participatory groups". HortTechnology 3:400403.

20. Purvis, A. I., Pipe, N. D., Day, J. P., Schattock, R. C., Shaw, D. S., and Assinder, S. J. 2001. AFLP and RFLP (RG57) fingerprints can give conflicting evidence about the relatedness of isolates of Phytophthora infestans. Mycol. Res. 105:1321-1331.
21. Rogers, S. O., and Bendich, A. J. 1985. Extraction of DNA from milligram amounts of fresh, herbarium and mummified plant tissues. Plant Mol. Biol. 5:69-76.

22. Schnabel, G., Huang, H., Layne, D. R., and Jeffers, S. N. 2002. Phytophthora crown rot: Occurrence, diagnosis and control. Strawberry Grower 9:4-6

23. Schnabel, G., Schnabel, E. L., and Jones, A. L. 1999. Characterization of ribosomal DNA from Venturia inaequalis and its phylogenetic relationship to rDNA from other tree-fruit Venturia species. Phytopathology 89:100-108.

24. Seemüller, E. 1998. Crown rot. Pages 50-51 in: Compendium of Strawberry Diseases. 2nd ed. J. L. Maas, ed. American Phytopathological Society, St. Paul, MN

25. Shannon, C. E., and Weaver, W. 1949. The Mathematical Theory of Communication. University of Illinois, Urbana.

26. Slatkin, M., and Barton, N. H. 1989. A comparison of the three indirect methods for estimating average levels of gene flow. Evolution 43:1349-1368.

27. Tooley, P. W., O’Neill, N. R., Goley, E. D., and Carras, M. M. 2000. Assessment of diversity in Claviceps africana and other Claviceps species by RAM and AFLP analyses. Phytopathology 90:1126-1130.

28. van der Lee, T., DeWitte, I., Drenth, A., Alfonso, C., and Govers, F. 1997. AFLP linkage map of the oomycete Phytophthora infestans. Fungal Genet. Biol. 21:278-291.

29. Vos, P. E., Hogers, R., Bleeker, M., Reijians, M., van der Lee, T., Hornes, M., Frijters, A., Pot, J., Peleman, J., Kuiper, M., and Zabeau, M. 1995. AFLP: A new techique for DNA fingerprinting. Nucleic Acids Res. 23:4407-4414.

30. Weising, K., Nybom, H., Wolff, K., and Meyer, W. 1995. DNA Fingerprinting in Plants and Fungi. CRC Press, Boca Raton, FL.

31. Yeh, R. C., and Boyle, T. J. B. 1997. Population genetic analysis of co-dominant and dominant markers and quantitative traits. Belgian J. Bot. 129:157. 